\title{
Study on the Emission Characteristics of PCDD/Fs and Other Multiple Pollutants in Flue Gas from Sintering Plant in China
}

\author{
WANG HUI ${ }^{1,2 *}$, ZHANG PU ${ }^{1,2}$ \\ ${ }^{1}$ Central Research Institute of Building and Construction Co., Ltd, MCC Group, Beijing 100088, China \\ ${ }^{2}$ Energy-saving and Environmental Protection Co. Ltd. MCC Group, Beijing 100088, China
}

\begin{abstract}
In China, sintering flue gas has become the most important source of air pollution rather than burning coal-fired flue gas.The emission characteristics and removal efficiencies of various gaseous pollutants were studiedon a $180 \mathrm{~m}^{2}$ sintering equipped with a semi-dry oxidative desulfurization and denitrification system in Tangshang, Hebei province. The emission concentrations of particulate matter, fluoride, $\mathrm{NO}_{\mathrm{X}}$ and $\mathrm{SO}_{2}$ were measured in the flue gas whilepolychlorinated dibenzo-p-dioxins and dibenzofurans $(P C D D / F s)$ were tested in both flue gas and dust ash at 100\% and $60 \%$ loadconditions. The collections and analyses ofpollutantswere used by smoke sampler, TESTO350 and dioxin sampleraccording to national standards of China. The results shown that the average emission concentration of particulate matter, fluoride, $\mathrm{NO}_{\mathrm{X}}$ and $\mathrm{SO}_{2}$ in the inlet of the flue gas purification system were $47.4 \mathrm{mg} / \mathrm{m}^{3}, 0.12 \mathrm{mg} / \mathrm{m}^{3}, 150 \mathrm{mg} / \mathrm{m}^{3}$ and $521 \mathrm{mg} / \mathrm{m}^{3}$ while the emission concentrations in the outlet were $1.2 \mathrm{mg} / \mathrm{m}^{3}, 0.07 \mathrm{mg} / \mathrm{m}^{3}, 24 \mathrm{mg} / \mathrm{m}^{3}$ and $20 \mathrm{mg} / \mathrm{m}^{3}$,respectively. Through the flue gas purification system, the PCDD/Fs concentrations were reduced from 23.12 $\mathrm{ng} / \mathrm{m}^{3}$ to $1.14 \mathrm{ng} / \mathrm{m}^{3}$ at $100 \%$ load and from $12.25 \mathrm{ng} / \mathrm{m}^{3}$ to $0.84 \mathrm{ng} / \mathrm{m}^{3}$ at $60 \%$ load. The PCDD/Fs concentrations in the dust ash were about 178.56 197.21 $\mathrm{ng} / \mathrm{kg}$. Thedesulfurization and denitrification system significant reduced effect on the emission of particulate matter, fluoride, $\mathrm{NO}_{X}, \mathrm{SO}_{2}$ and PCDD/Fs with the value 97.5\%, 41.7\%, 84.0\%, 96.2\% and 95.1\% at 100\% load, respectively. The removal affects increases along the chlorination degree of PCDD/Fs. Meanwhile, the different load influenced the emission concentrations and removal rates of PCDD/Fs in the flue gas, the removal effects increases as the load increases. Although the desulfurization and denitrification system has good removal effects on various pollutants, the dioxins were enriched in the dust ashso as to cause secondary pollution.
\end{abstract}

Keywords: sintering flue gas, PCDD/Fs, gaseous pollutants, oxidative desulfurization and denitrification, removal effect

\section{Introduction}

Nowadays, steel industry has become an important pillar industry of the national economy. With the increase of steel production capacity. The problem of air pollution in China's steel industry become increasingly seriously. The flue gas of the sintering machine head is the main source of atmospheric pollutants in the steel plant. The pollutants emitted by the sintering machine head mainly include particulate matter, $\mathrm{SO}_{2}, \mathrm{NO}_{x}$, fluoride, and dioxins [1], especially dioxin emissions [2] account for more than one-third of the entire plant, and the sintering head flue gas is also the most important source of dioxin emissions in China except for waste incineration. At present, in China, it has a comprehensive study on the emission characteristics of atmospheric pollutants from coal-fired power plants and waste incineration plant [3-6], but the research on the emission characteristics of sintering heads has just started $[4,7]$. Compared with foreign studies $[8,9]$, there is a lack of basic data on the emission characteristics of various pollutants in steel plants, as well as monitoring results under different operating loads [8-25].

*email:Wanghui@cribc.com 
Sintering is currently the focus of China's iron and steel enterprises pollution emission. In order to improve the atmospheric environment, China's environmental protection department has set the most stringent ultra-low emission standards for the sintering flue gas, which were $10 \mathrm{mg} / \mathrm{m}^{3}$ for particulates, $35 \mathrm{mg} / \mathrm{m}^{3}$ for $\mathrm{SO}_{2}, 50 \mathrm{mg} / \mathrm{m}^{3}$ for $\mathrm{NO}_{\mathrm{X}}, 3.0 \mathrm{mg} / \mathrm{m}^{3}$ for fluoride and $0.5 \mathrm{ng}-\mathrm{TEQ} / \mathrm{m}^{3}$ for dioxins. And then many steel companies have installed a large number of new flue gas purification devices. In the treatment process, a variety of comprehensive dedusting, desulfurization, denitrification and dioxins removal technologies have been applied, which are including catalytic oxidation absorption method, medium temperature selective catalytic reduction(SCR) method, activated carbon/coke adsorption method, etc. However, the researches on the impact of purification devices on the emission characteristics of various pollutants is limited, which are not conducive to mastering the actual total contaminant emissions. In particular, a catalytic oxidation absorption technology of circulating fluidized bed has been applied to the treatment of steel sintering flue gas in Hebei province. The impact of this technology on the emission of various pollutants and the removal efficiency of the flue gas remains to be further studied.

At the same time, the sintered dioxin emissions problem has always been the focal point of attention of researchers. Dioxins as known as Polychlorinated dibenzo-p-dioxins and dibenzofurans(PCDD/Fs) listed by the Stockholm Convention(UNEP 2002)are a family of pollutants whose most toxic congener(2,3,7,8-TCDD) has been classified as carcinogenic for humans by the International Agency for the Research on Cancer[3,4,24]. In China, dioxin emission guidelines for iron ore sintering were first implemented in 2012. It is estimated that there are about $10.2 \mathrm{~kg} / \mathrm{TEQ}$ of dioxin emissions per year from various sources, in China [26]. In order to control PCDD/Fs emissions, various end-of-pipe treatment technologies have been developed [27], such as catalytic decomposition using SCR catalysts [28,29], installing a fixed-bed adsorption system [30] and as well as spraying of powdered activated carbon [31] into flue gas and bag filter system with activated carbon adsorption [32-36] which the removal efficiency could reach to $95 \%$, and even higher. But the researches on dioxin in China mainly focused on the emission concentration after sintering machine bellows and electrostatic precipitator(ESP). Conversely, the impact of new ultra-low emission purification devices on the emission of dioxin in flue gas and the distribution of dioxin in by-products of purification equipment are lacking.

Based on the multi-polluting purification device for sintering flue gas by oxidation absorption method, this study investigated the removal effects and total emissions of particulate matter, $\mathrm{SO}_{2}, \mathrm{NO}_{\mathrm{X}}$ and fluoride, as well as the distribution characteristics and purification effects of dioxins in the flue gas under two distinct load conditions. Furthermore, the dioxins in the by-products of the flue gas purification equipment was also tested to prove the basic reference for the harmless treatment of dust ash.

\section{Materials and methods}

\subsection{Selecting a template}

The experiments were carried out in a $180 \mathrm{~m}^{2}$ sintering machine in Tangshang, Hebei province. In order to remove various harmful pollutants such as $\mathrm{NO}_{\mathrm{X}}, \mathrm{SO}_{2}$, particulate matter,fluoride, $\mathrm{PCDD} / \mathrm{Fs}$, etc. from the sintering flue gas, the oxidative desulfurization and denitrificationtechnology were applied. The sampling points were shown in Figure 1. This sampling system mainly consists of three part, the sintering line unit, the oxidative desulfurization and denitrification unit(flue gas treatment unit) and gas emission unit. The sintering line unit includes sintering strand, ESP and fan. The oxidative desulfurization and denitrification unit includes catalytic oxidation device, circulating fluidized bed(CFB), bag filter and ash warehouse. The gas emission unit includes booster fan and stack.

Firstly, the flue gas enters the oxidative desulfurization and denitrification unit after through the preliminary treatment of the ESP. The catalytic oxidation device oxidized NO becomes $\mathrm{NO}_{2}$ when the flue gas passing through. In the CFB system, the semi-dry technique was used. Meanwhile, the slaked 
limes were injected into the CFB to remove target $\mathrm{NO}_{2}$ and $\mathrm{SO}_{2}$. The slaked lime can be recycled by the bag filter and reused in the CFB, while the ashes were collected in the ash warehouse. Finally, the cleaned flue gas by the bag filter is discharged through the stack.

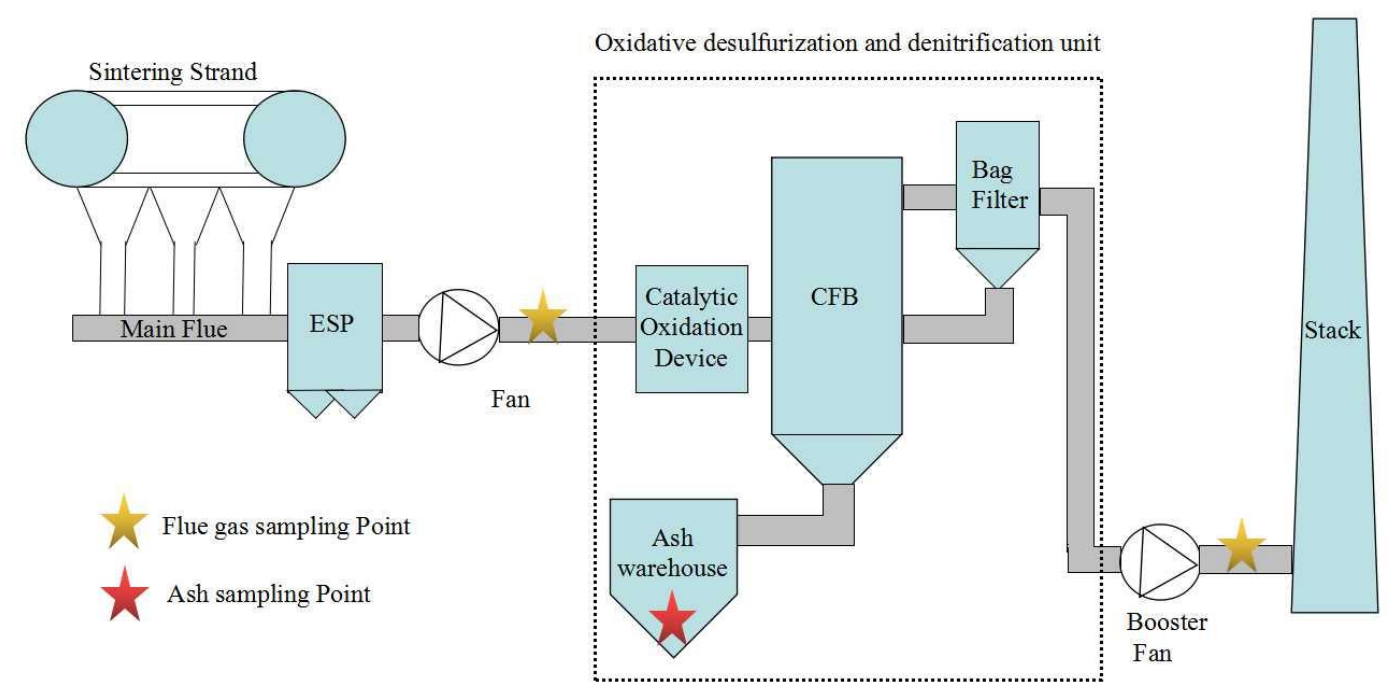

Figure 1. The sampling diagram

In this study we explored the effect of the oxidative desulfurization and denitrification unit on the removal of particulate matter, fluoride, $\mathrm{NO}_{\mathrm{X}}, \mathrm{SO}_{2}$ and 2,3,7,8-substituted PCDD/Fs in flue gas and the 2,3,7,8-substituted PCDD/Fs content in the ash. The sampling points were defined before catalytic oxidation device as inlet and before stack as outlet. All targeted pollutants were both tested in the inlet and outlet at full load working condition, while PCDD/Fs were not only tested at $100 \%$ load but also at $60 \%$ load.

Table 1. Sampling parameters of flue gas.

\begin{tabular}{lllll}
\hline Parameter & W1 Inlet & W1 Outlet & W2 Inlet & W2 Outlet \\
\hline Temperature $\left({ }^{\circ} \mathrm{C}\right)$ & 120 & 80 & 120 & 81 \\
\hline Moisture content $(\%)$ & 8.8 & 9.3 & 8.8 & 9.5 \\
\hline Standard dry flow $\left(\mathrm{m}^{3} / \mathrm{h}\right)$ & 594,940 & 497,890 & 351,700 & 490,350 \\
\hline Oxygen content $(\%)$ & 16.0 & 16.4 & 16.0 & 16.3 \\
\hline Flow velocity $(\mathrm{m} / \mathrm{s})$ & 12.4 & 15.3 & 1.2 & 15.4 \\
\hline \multicolumn{7}{c}{$\begin{array}{c}\text { Working condition W1: } \\
\text { Working condition W2:60\% load. }\end{array}$} \\
\hline
\end{tabular}

The smoke sampling parametersin both inlet and outlet were shown in Table 1.In the inlet, the standard dry flow of W1 is about $600,000 \mathrm{~m}^{3} / \mathrm{h}$, while the standard dry flow of W2 is about 350,000 $\mathrm{m}^{3} / \mathrm{h}$. Due to the presence of the booster fan, the outlet gas flow of 2 working conditions were all about $500,000 \mathrm{~m}^{3} / \mathrm{h}$.

\subsection{Sampling and Quantification Methods}

\subsubsection{Particulate matter}

The sampling of particulate matter is based on National Environmental Protection Standard of the People's Republic of China -- HJ836-2017 (i.e. Stationary source emission -- Determination of mass concentration of particulate matter at low concentration -- Manual gravimetric method). Before sampling, the front elbow, sealing aluminum ring and the steel support should be cleaned to remove the particles that may be adsorbed. At the same time, quartz filter should be baked for $1 \mathrm{~h}$ at $180{ }^{\circ} \mathrm{C}$. After cooling, the filter, steel plate and elbow are assembled together with a sealed aluminum ring. 


\subsubsection{Fluoride}

The sampling of fluoride is based on National Environmental Protection Standard of the People's Republic of China -- HJ/T67-2001 (i.e. Stationary source emission -- Determination of fluoride -- Ion selective electrode method). The collected fluoride is stored in a polyethylene bottle. A sample of unknown concentration fluoride was titrated with hydrochloric acid using bromocresol green as indicator.

\subsection{3. $\mathrm{NO}_{x}$ and $\mathrm{SO}_{2}$}

The sampling of $\mathrm{NO}_{\mathrm{X}}$ and $\mathrm{SO}_{2}$ are based on National Environmental Protection Standard of the People's Republic of China -- HJ 693-2014 (i.e. Stationary source emission -- Determination of nitrogen oxides--Fixed potential by electrolysis method) and HJ 57-2017 (i.e. Stationary source emission -- Determination of sulfur dioxide--Fixed potential by electrolysis method). Both $\mathrm{NO}_{\mathrm{x}}$ and $\mathrm{SO}_{2}$ were measured using an automatic tester (Testo 350). Place the front end of the analyzer sampling tube on the sampling point and ensure no air leakage.

\subsubsection{PCDD/Fs}

The sampling of 2,3,7,8-substituted PCDD/Fs is based on National Environmental Protection Standard of the People's Republic of China -- HJ/T77-2001 (i.e. Determination of polychlorinated dibenzo- $p$-dioxins and polychlorinated dibenzo- $p$-furans by isotope dilution HRGC/HRMS).

Each sample was spiked with ${ }^{13} \mathrm{C}_{12}$-labelled internal standards and then Soxhlet extracted by toluene. The extracts were purified with a series cleanup silica gel column, include sulfuric acid gel column and multi-layer silica gel column [37]. Samples were analyzed by DSF High Resolution Gas Chromatography-Mass Spectrometry. The total toxic equivalents (TEQ) concentration was calculated using international toxic equivalency factors (I-TEFs) [38-40].

\section{Results and discussions}

\subsection{Removals of Particles, Fluoride, Nox, and $\mathrm{SO}_{2}$}

The emission concentrations of particulate matter, fluoride, $\mathrm{NO}_{\mathrm{x}}$ and $\mathrm{SO}_{2}$ were investigated in this study. The various substances in the flue gas were significantly reduced when going through the oxidative desulfurization and denitrification unit. The concentrations of particulate matter, fluoride, $\mathrm{NO}_{\mathrm{X}}$ and $\mathrm{SO}_{2}$ in both inlet and outlet and the removal rates (Figure 2).

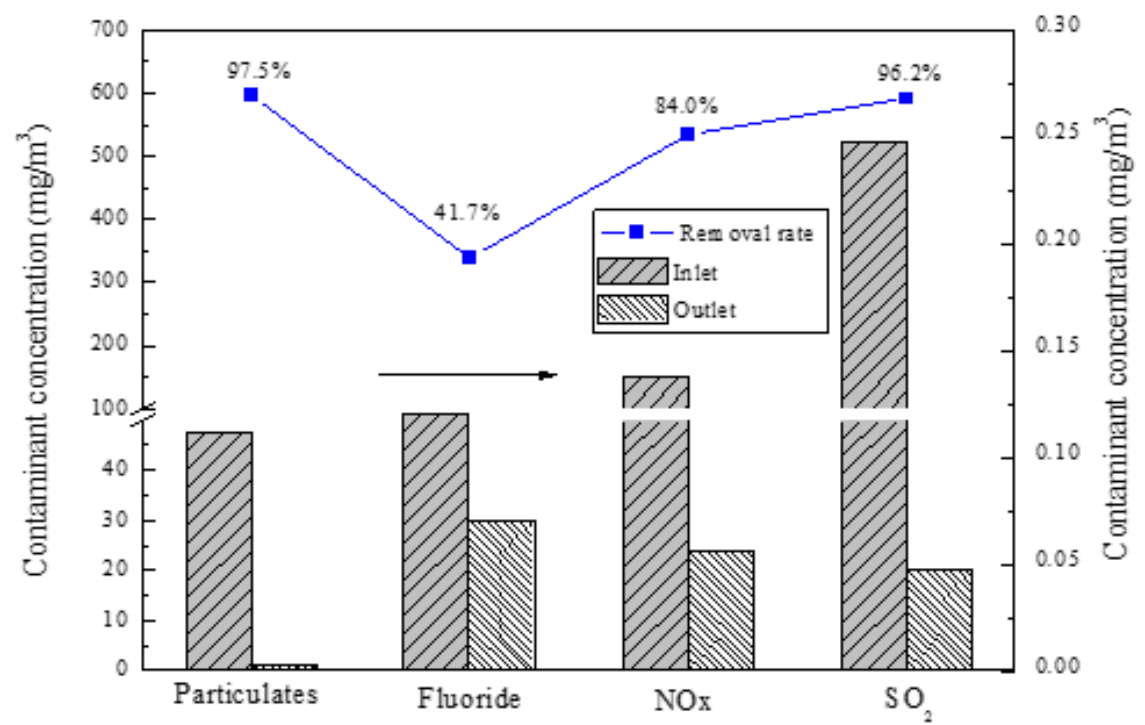

Figure2.Concentrations and removal rates of particulate, fluoride, $\mathrm{NO}_{\mathrm{X}}$ and $\mathrm{SO}_{2}$ in inlet and outlet 
In the inlet, the average emission values of particulate matter, fluoride, $\mathrm{NO}_{\mathrm{x}}$ and $\mathrm{SO}_{2}$ in the flue gas were $47.4 \mathrm{mg} / \mathrm{m}^{3}, 0.12 \mathrm{mg} / \mathrm{m}^{3}, 150 \mathrm{mg} / \mathrm{m}^{3}$ and $521 \mathrm{mg} / \mathrm{m}^{3}$,respectively. Meanwhile the outlet emission concentrations of those pollutants were tested as $1.2 \mathrm{mg} / \mathrm{m}^{3}$ (particulate matter), $0.07 \mathrm{mg} / \mathrm{m}^{3}$ (fluoride), $24 \mathrm{mg} / \mathrm{m}^{3}(\mathrm{NO})$ and $20 \mathrm{mg} / \mathrm{m}^{3}\left(\mathrm{SO}_{2}\right)$. Obviously, the oxidative desulfurization and denitrification unit had excellent removal effects on particulate matter and $\mathrm{SO}_{2}$ with the removal rates up to $97.5 \%$ and $96.2 \%$, respectively. Meanwhile, the fluoride removal rate was the weakest among these pollutants removal rate with the value of $41.7 \%$. The emissions of particulate matter, fluoride, $\mathrm{NO}_{\mathrm{X}}$ and $\mathrm{SO}_{2}$ were all lower than the latest ultra-low emission standards in China. And the total mass flowemission rates of particulate matter, fluoride, $\mathrm{NO}_{\mathrm{X}}$ and $\mathrm{SO}_{2}$ in the stack were $0.6 \mathrm{~kg} / \mathrm{h}, 34.8 \mathrm{~g} / \mathrm{h}, 12.0 \mathrm{~kg} / \mathrm{h}$ and 10.0 $\mathrm{kg} / \mathrm{h}$, respectively.

\subsection{Removals of PCDD/Fs}

The flue gas treatment unit not only decreasing the concentrations of particulate matter, fluoride, $\mathrm{NO}_{\mathrm{X}}$ and $\mathrm{SO}_{2}$ but also had a significant removal effect on PCDD/Fs at the same time. The total emission concentrations of 2,3,7,8-substituted PCDD/Fs and I-TEQ values at 2 working conditions were shown in Tables 2 and 3.

Table 2. Concentrations and removal rates of 2,3,7,8-substituted PCDD/Fs in flue gas and ash at 2 working conditions ininlet and outlet.

\begin{tabular}{|c|c|c|c|c|c|c|}
\hline & W1 Inlet & W1 Outlet & W2 Inlet & W2 Outlet & Ash1 & Ash2 \\
\hline & $\mathrm{ng} / \mathrm{m}^{3}$ & & & & $\mathrm{ng} / \mathrm{kg}$ & \\
\hline$\sum$ PCDDs & 2.69 & 0.10 & 1.67 & 0.10 & 449.93 & 327.29 \\
\hline$\sum$ PCDFs & 20.43 & 1.04 & 10.58 & 0.74 & 1986.00 & 1854.10 \\
\hline TEQ- $\sum$ PCDDs & 0.21 & 0.02 & 0.10 & 0.02 & 19.14 & 14.06 \\
\hline TEQ- $\sum$ PCDFs & 2.23 & 0.15 & 1.03 & 0.09 & 178.07 & 164.50 \\
\hline$\sum \mathrm{PCDD} / \mathrm{Fs}$ & 23.12 & 1.14 & 12.25 & 0.84 & 2435.93 & 2181.39 \\
\hline$\sum$ TEQ & 2.44 & 0.17 & 1.13 & 0.11 & 197.21 & 178.56 \\
\hline \multicolumn{7}{|l|}{ Rate of PCDD/Fs } \\
\hline PCDDs/ $/$ PCDD/Fs & 0.12 & 0.09 & 0.14 & 0.12 & 0.18 & 0.15 \\
\hline $\mathrm{PCDFs} / \sum \mathrm{PCDD} / \mathrm{Fs}$ & 0.88 & 0.91 & 0.86 & 0.88 & 0.82 & 0.85 \\
\hline PCDFs/PCDDs & 7.58 & 10.02 & 6.34 & 7.17 & 4.41 & 5.67 \\
\hline TEQ-PCDDs/2PCDD/Fs & 0.09 & 0.12 & 0.09 & 0.14 & 0.10 & 0.08 \\
\hline TEQ-PCDFs/ $/$ PCDD/Fs & 0.91 & 0.88 & 0.91 & 0.86 & 0.90 & 0.92 \\
\hline TEQ-PCDFs/PCDDs & 10.45 & 7.36 & 9.94 & 6.38 & 9.30 & 11.70 \\
\hline \multicolumn{7}{|l|}{ Removal rate $(\%)$} \\
\hline PCDDs & 96.16 & & 93.77 & & & \\
\hline PCDFs & 94.93 & & 92.97 & & & \\
\hline TEQ-PCDDs & 90.43 & & 85.10 & & & \\
\hline TEQ-PCDFs & 93.26 & & 90.43 & & & \\
\hline Total-PCDD/Fs & 95.07 & & 93.08 & & & \\
\hline
\end{tabular}

Table 3. Total emissions and removal rates of PCDD/Fsin inlet and outlet.

\begin{tabular}{cll}
\hline Sampling & Total emissions $(\mathrm{g} / \mathrm{h})$ & Removal rate $(\%)$ \\
\hline W1 Inlet & 13.76 & 95.87 \\
\hline W1 Outlet & 0.57 & \\
\hline W2 Inlet & 7.29 & 94.26 \\
\hline W2 Outlet & 0.42 & \\
\hline
\end{tabular}

At full load, the mean emission values of 2,3,7,8-substituted PCDD/Fs in both inlet and outlet flue gas were 23.12 and $1.14 \mathrm{ng} / \mathrm{m}^{3}$, respectively. And the total TEQ values of 2,3,7,8-substituted PCDD/Fs were 2.44 and $0.17 \mathrm{ng} \cdot \mathrm{TEQ} / \mathrm{m}^{3}$. Due to the immaturity of current emission reduction technologies, the concentrations of $\mathrm{PCDD} / \mathrm{Fs}$ produced during the steel sintering process were higher than the $\mathrm{PCDD} / \mathrm{Fs}$ concentrations $\left(0.0054-0.1961 \mathrm{ng} \cdot \mathrm{TEQ} / \mathrm{m}^{3}\right)$ in flue gas from municipal solid waste with typical fluidized bed incinerators [41]. Conversely, the concentration of PCDD/Fs emitted during the steel sintering process was similar with the concentration of medical waste incinerators(MWIs), which the 
total TEQs of PCDD/Fs in stack gas from MWIs were 0.031 to $3.463 \mathrm{ng} \cdot \mathrm{TEQ} / \mathrm{m}^{3}$ [42]. The oxidative desulfurization and denitrification unit showed a remarkable removal efficiency on 2,3,7,8-substituted PCDD/Fs with the removal rate of $95.07 \%$, which mainly removed96.16\% of PCDDs. Meanwhile the total PCDD/Fs emissiom concentration was $13.76 \mathrm{~g} / \mathrm{h}$ in the inlet and $0.57 \mathrm{~g} / \mathrm{h}$ in the outlet, and the removal rate of total PCDD/Fs was $95.87 \%$.

Compared with the full load, the emission values of 2,3,7,8-substituted PCDD/Fs at $60 \%$ load were slightly reduced to $12.25 \mathrm{ng} / \mathrm{m}^{3}$ (concentration), $1.13 \mathrm{ng} \cdot \mathrm{TEQ} / \mathrm{m}^{3}$ (TEQ) in theinlet and 0.84 $\mathrm{ng} / \mathrm{m}^{3}$ (concentration), $0.11 \mathrm{ng} \cdot \mathrm{TEQ} / \mathrm{m}^{3}$ (TEQ) in the outlet. In addition, the emission value of $2,3,7,8$ substituted PCDD/Fs decreased significantly with removal rate of $93.08 \%$ which was lightly lower than at full load. The total PCDD/Fs emissions in both inlet and outlet were $7.29 \mathrm{~g} / \mathrm{h}$ and $0.42 \mathrm{~g} / \mathrm{h}$ with removal rates of $94.26 \%$, which were all lower than at full load. No matter W1 andW2, the PCDD/Fs emitted from the stack were all below the China emission standard of $0.5 \mathrm{ng} \cdot \mathrm{TEQ} / \mathrm{m}^{3}$.

Furthermore, the formation of PCDD/Fs in the flue gas at the steel sintering process was widely recognized as a typical de novo synthesis pathway [39,40]. Both inlet and outletat2 working conditions, PCDFs dominated among the total amounts of PCDD/Fs, which accounted for 86 to $91 \%$ of the total yield. The rates of PCDFs to PCDDs were about 6.34 to 10.02(>1), which conformed to the characteristics of the de novo synthesis pathway(Table 2). Additional, distinct loads had a certain effect on the concentrations of PCDD/Fs. The full load had greater the concentrations of PCDD/Fs.

Figure 3 showed the concentrations and removal rates of 2,3,7,8-substituted PCDD/Fs homologues in the inlet and outlet at 2 working conditions. Obviously shown in Figures 3a and 3b, $1,2,3,7,8-\mathrm{PeCDD}$ was the main component in PCDDs while 2,3,4,7,8-PeCDF was the main product in PCDFs in both inlet and outletatW1. In addition, among the homologues of PCDD/Fs, OCDD and OCDF had the highest removal rates with $98.18 \%$ and $98.05 \%$, respectively. Conversely, 2,3,7,8TCDD was the worst removalrate at $83.96 \%$. AtW2, PCDD/Fs distribution showed a same trendin both inlet and outlet. OCDD and OCDF had the highest removal rate with the values of $96.63 \%$ and $97.83 \%$. And also 2,3,7,8-TCDD showed the worst removal rate at $76.15 \%$.

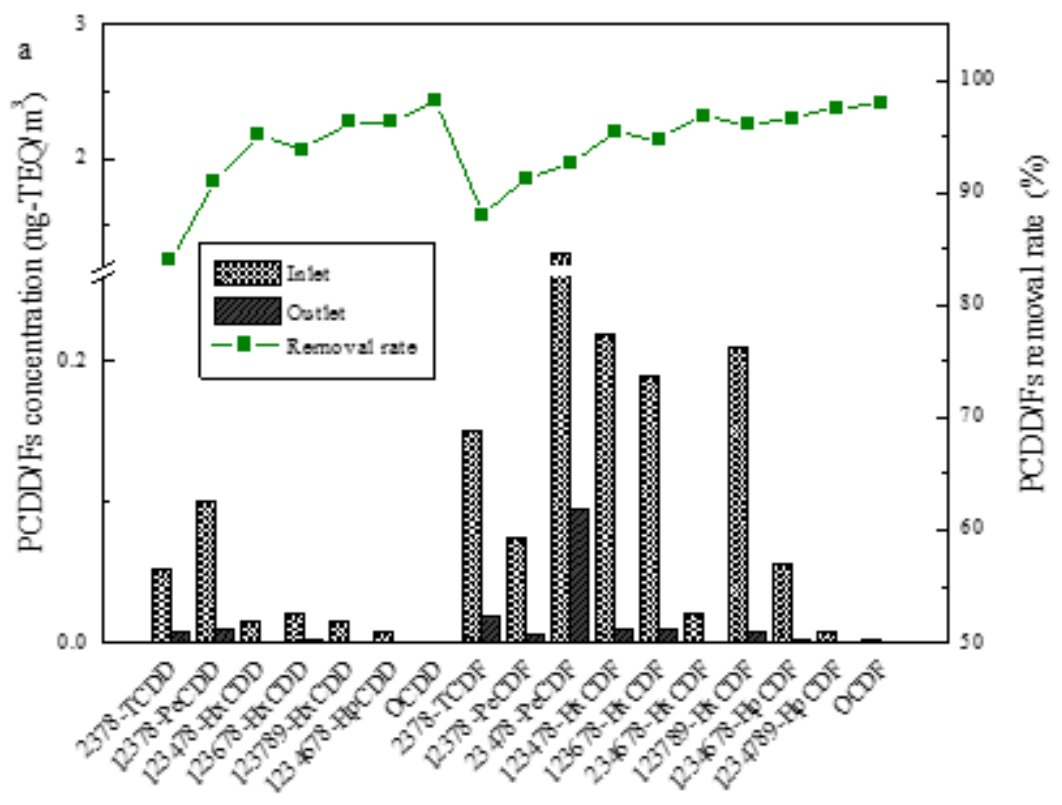



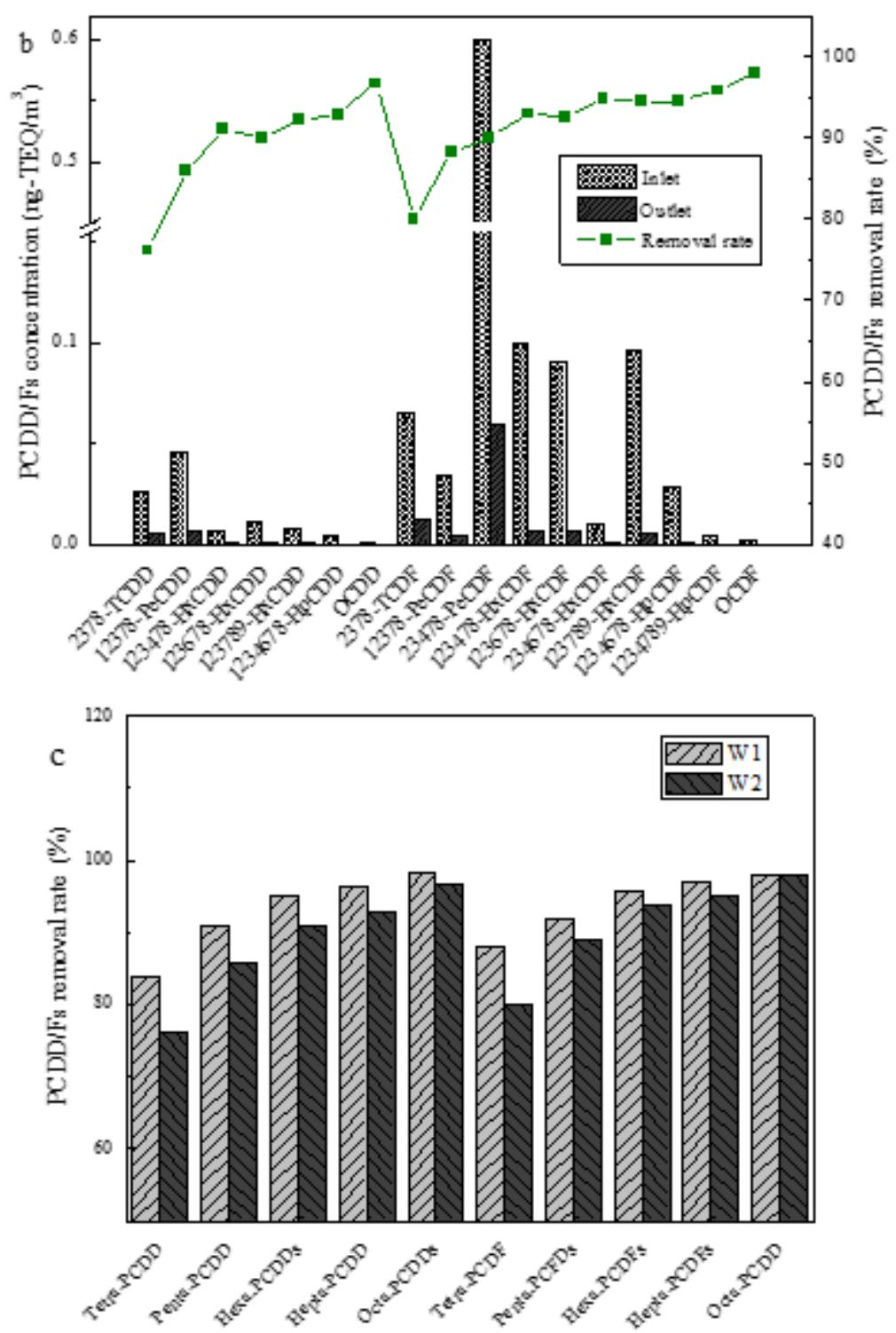

Figure 3. PCDD/Fs concentration and removal rate atW1(a) and at $\mathrm{W} 2(\mathrm{~b}), \mathrm{PCDD} / \mathrm{Fs}$ homologues removal rate atW1 and W2(c) .

Figure 3c summarized the removal rates of 2,3,7,8-substituted PCDD/Fs homologues at 2working conditions. In general, compared with $60 \%$ load, the oxidative desulfurization and denitrification unit had a better effect on removing PCDD/Fs at full load. Moreover, the removal effect increased as the chlorination of $\mathrm{PCDD} / \mathrm{Fs}$ increased at 2 working conditions. The removal rates were sorted as follows: Octa-PCDD/Fs $>$ Hepta-PCDD/Fs $>$ Hexa-PCDD/Fs $>$ Penta-PCDD/Fs $>$ Tetra-PCDD/Fs, which showed that the oxidative desulfurization and denitrification unit was more efficient to remove high chlorinated $\mathrm{PCDD} / \mathrm{Fs}$ rather than low chlorinated PCDD/Fs. It is possible that another reason may lead to the result that slaked lime acted as both adsorbent and catalyst promotes dechlorination of PCDD/Fs.

\subsection{Homologue Distributions of PCDD/Fs}

The homologue distributions of PCDD/Fs were often referred to as its 'fingerprint' or 'signature', which was used to indicate the emission characteristics of PCDD/Fs [41,42]. Figure 4 shown the homologue distributions of PCDD/Fs 2,3,7,8-substituted were obtained from the flue gas at 2 working conditions. 

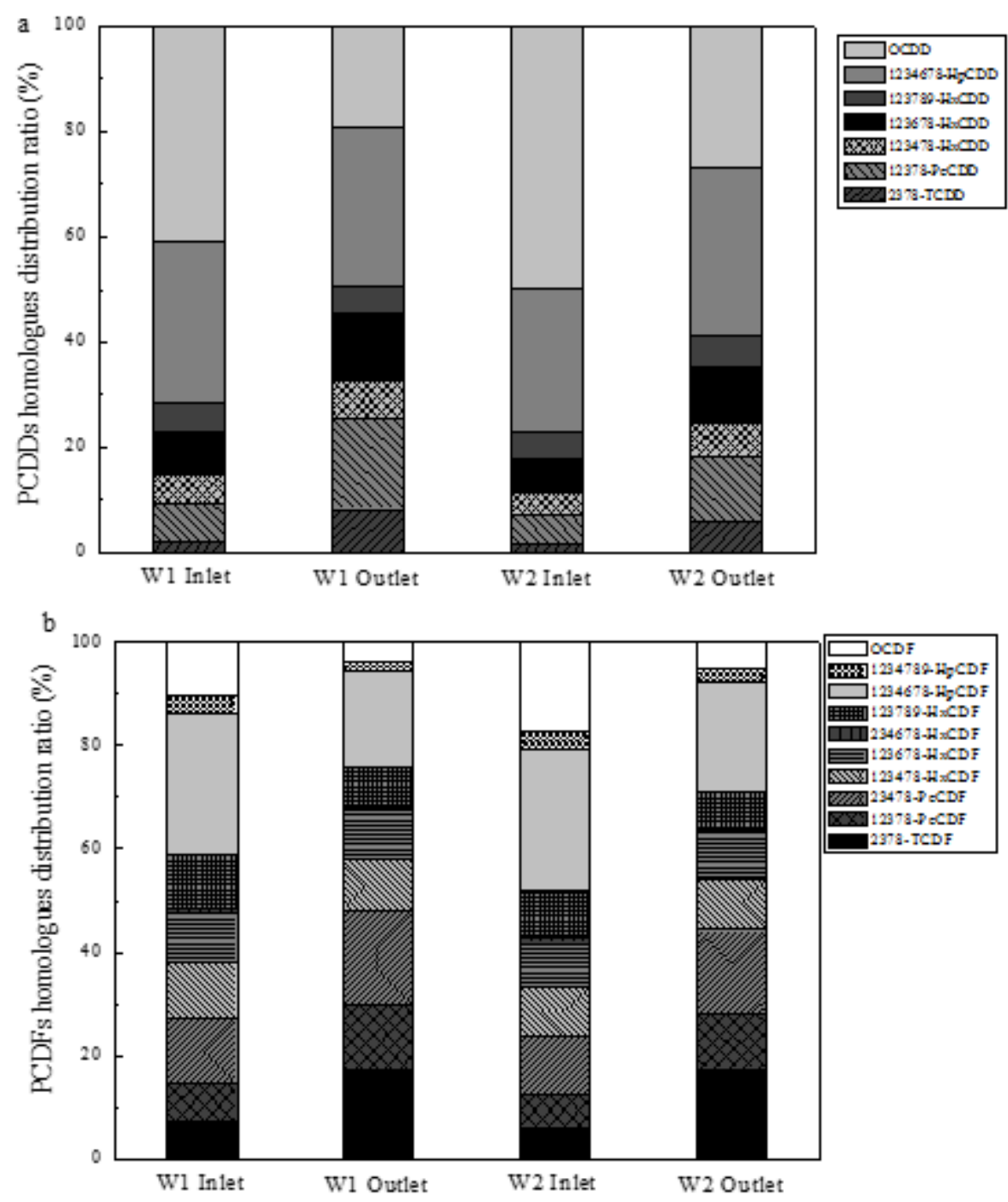

Figure 4.PCDDs(a) and PCDFs(b) homologues distribution ratio in flue gasat $\mathrm{W} 1$ and $\mathrm{W} 2$.

Whether W1 or W2 in the inlet, OCDD was the main component of PCDDs, accounting for about 40.85\%(W1) and 49.70\%(W2). Secondly, 1,2,3,4,6,7,8-HpCDD accounted for $30.82 \%(\mathrm{~W} 1)$ and 27.54\%(W2), while the ratios of other chlorine substituted PCDDs were below $10 \%$, especially 2,3,7,8-TCDD only accounted for $1.97 \%(\mathrm{~W} 1)$ and $1.56 \%(\mathrm{~W} 2)$. For PCDFs in the inlet, 1,2,3,4,6,7,8HpCDF dominated at $27.41 \%$ at 2 working conditions. In contrast, the ratios of $1,2,3,4,7,8,9-\mathrm{HpCDF}$ accounted $1.03 \%(\mathrm{~W} 1)$ and $0.95 \%(\mathrm{~W} 2)$, which was the least proportion of PCDFs.

In the outlet, PCDDs homologous distribution in full load and $60 \%$ load showed similar characteristics. Compared with the inlet, $1,2,3,4,6,7,8-\mathrm{HpCDD}$ became the main product rather than OCDD, OCDD rate ranked the second which was slightly lower than $1,2,3,4,6,7,8-\mathrm{HpCDD}$. The ratio of $1,2,3,7,8$-PeCDD was more than doubled than in the inlet while 2,3,7,8-TCDD was still the least product. For PCDFs, the proportion of 2,3,7,8-TCDF was doubled approximately. Additionally, the rest chlorine substituted PCDFs were average distributed compared with inlet distribution. Furthermore, the 2 working conditions do not influence the distribution characteristics, which showed that the flow rate has no significant effect on the homologues distribution ratios of PCDD/Fs.

\subsection{Distributions of Dioxins in Dust Ash}

In order to figure out the comprehensive distribution characteristics of $\mathrm{PCDD} / \mathrm{Fs}$, the dust ash was also collected and analyzed in this study. The concentrations of PCDD/Fs in the dust ash atW1 and W2 
were $2435.93 \mathrm{ng} / \mathrm{kg}$ (concentration), $197.21 \mathrm{ng} \cdot \mathrm{TEQ} / \mathrm{m}^{3}$ (TEQ) and $2181.39 \mathrm{ng} / \mathrm{kg}$ (concentration), $178.56 \mathrm{ng} \cdot \mathrm{TEQ} / \mathrm{m}^{3}$ (TEQ), respectively (Table 2). PCDD/Fs concentrations were far lower than that the average concentration of PCDD/Fs augmented from $73.47 \mathrm{ng} / \mathrm{g}$ in boiler ash to $95.49 \mathrm{ng} / \mathrm{g}$ in filter ashat waste incineration process. However, the concentrations of PCDFs were significantly higher than that of PCDDs. PCDFs were still the main products in the dust ash, the generation amounts of PCDFs were 4.41 to 5.67 times that of PCDDs while TEQ concentrations of PCDFs were 9.30 to 11.7 times that of PCDDs.

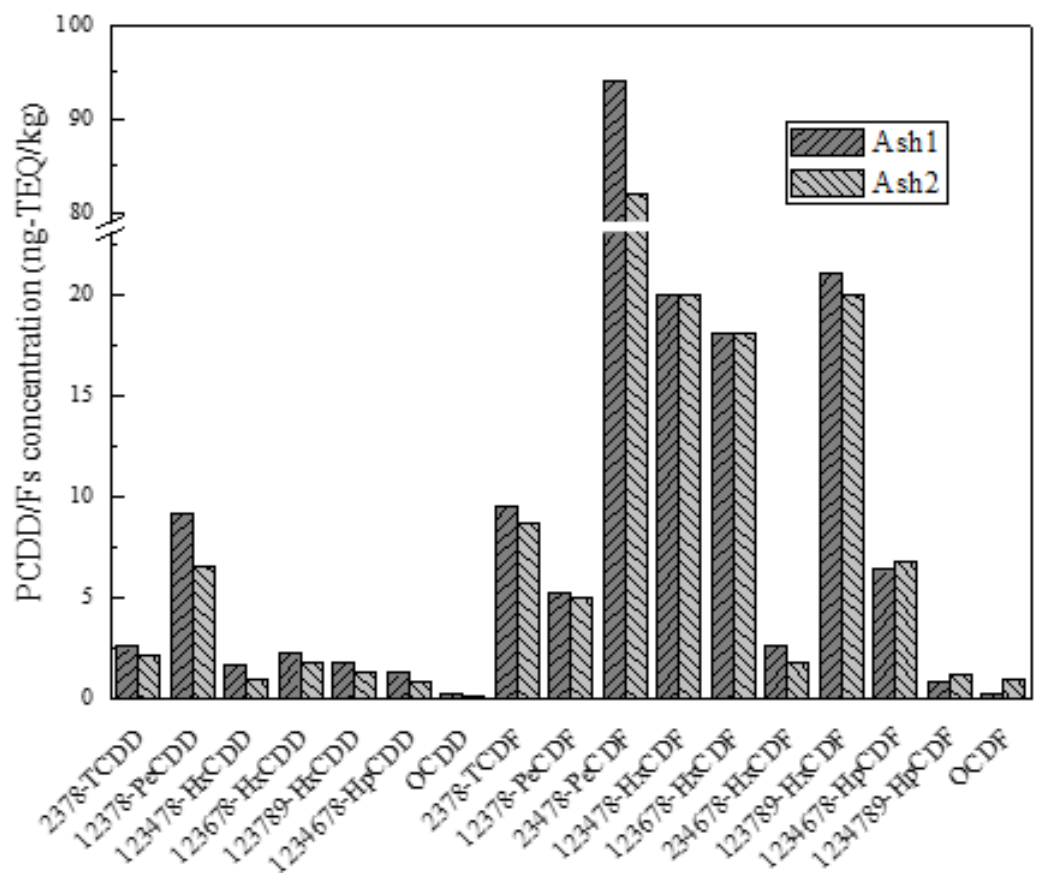

Figure 5. PCDD/Fs homologues concentration in dust ashatW1 and W2.

Figure 5 reveals the PCDD/Fshomologues concentrations in the dust ashes atW1 and W2. In both cases, the homologues distribution patterns of PCDD/Fs were almost the same. 1,2,3,7,8-PeCDD was the main chlorinated product of PCDDs with the ratios of $48.07 \%(\mathrm{~W} 1)$ and $46.94 \%(\mathrm{~W} 2)$, which were also consistent with the homologues distribution characteristics in the flue gas. At the same time, 2,3,4,7,8-PeCDF was the highest content in total PCDFs. More comprehensive contents were shown in Figure 6. The results showed that the different loads have no significant effect on the homologues distributions of PCDD/Fs [40-50].

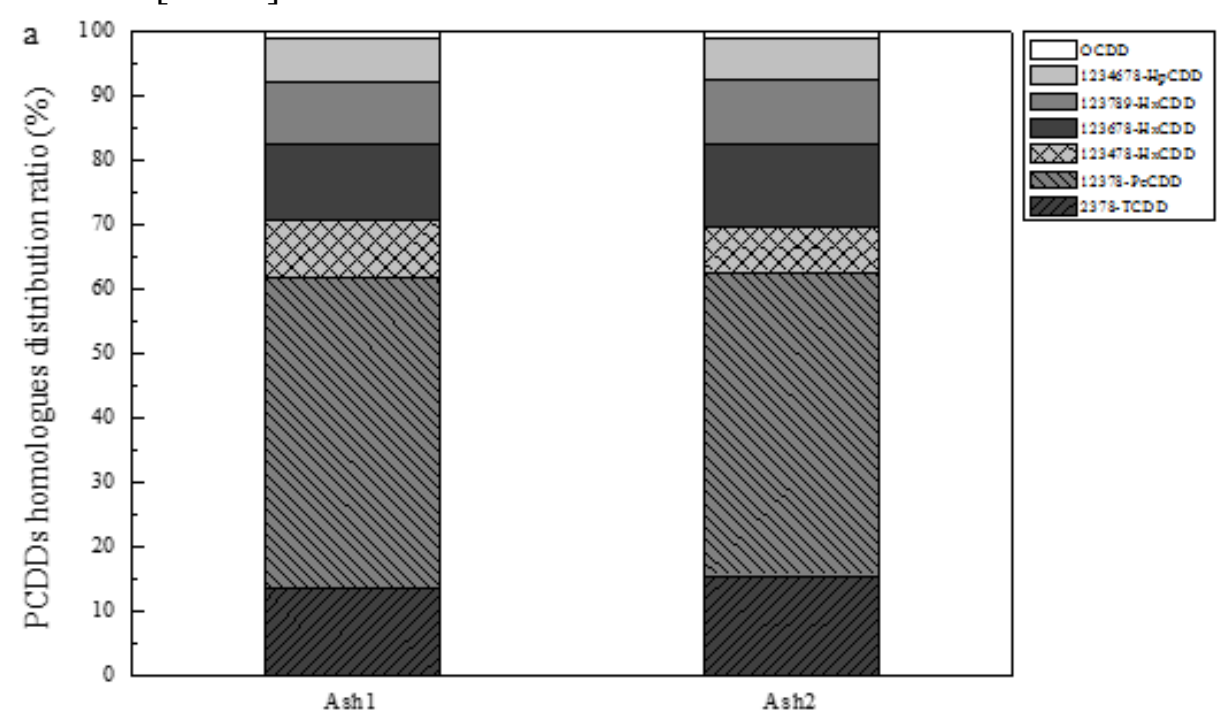




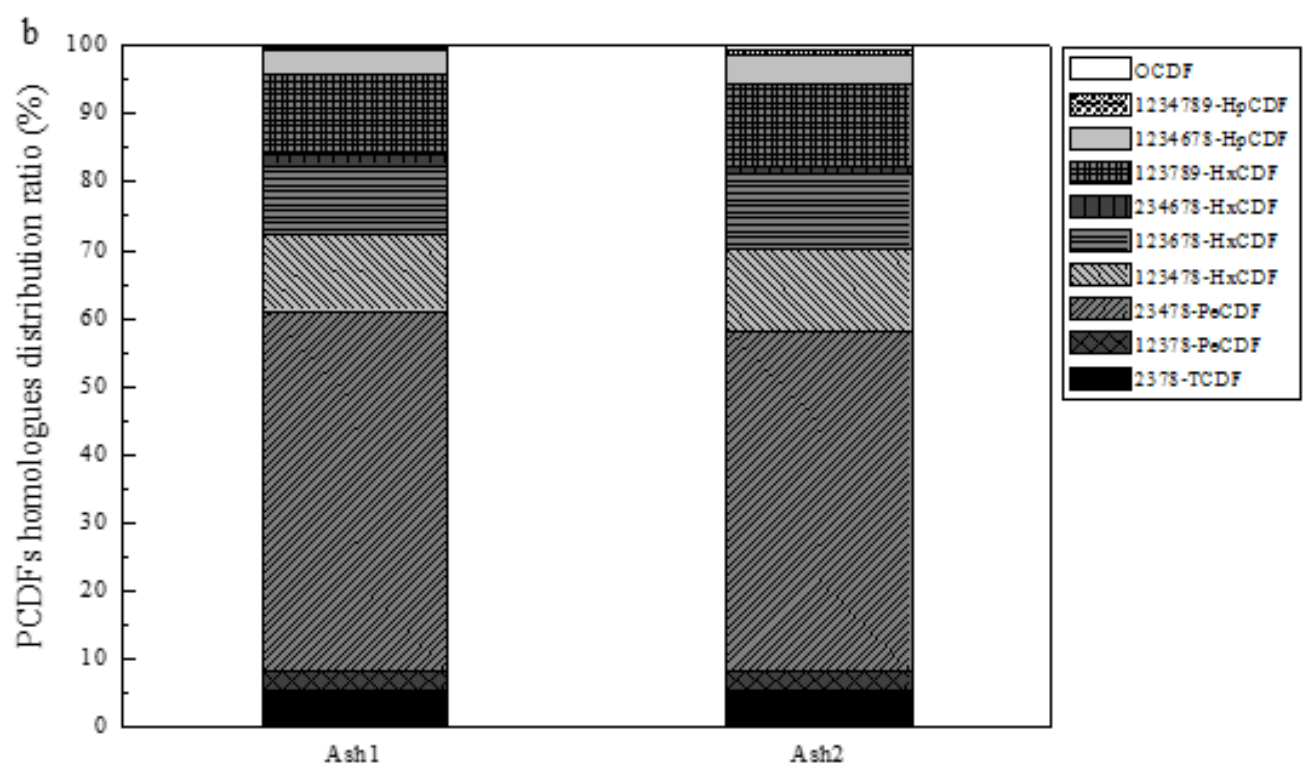

Figure 6.PCDDs(a) and PCDFs(b) homologues concentration ratein dust ash at W1 and W2.

\section{Conclusions}

This study focused on the removal effects and emission distribution characteristics of particulate matter, $\mathrm{SO}_{2}, \mathrm{NO}_{\mathrm{X}}$, fluoride and dioxins in the sintering flue gas with an oxidative desulfurization and denitrification system. The results showed:

(1) The emissionconcentrations of particulate matter, fluoride, $\mathrm{NO}_{\mathrm{X}}, \mathrm{SO}_{2}$ and $\mathrm{PCDD} / \mathrm{Fs}$ were reduced dramatically to $1.2 \mathrm{mg} / \mathrm{m}^{3}, 0.07 \mathrm{mg} / \mathrm{m}^{3}, 24 \mathrm{mg} / \mathrm{m}^{3}, 20 \mathrm{mg} / \mathrm{m}^{3}$ and $0.17 \mathrm{ng} \cdot \mathrm{TEQ} / \mathrm{m}^{3}(100 \%$ load condition), $0.11 \mathrm{ng} \cdot \mathrm{TEQ} / \mathrm{m}^{3}(60 \%$ load condition), respectively, which were all under the ultra-low emission standards in China.

(2) The oxidationpurification device of sintering flue gas had remarkable removal effects of various pollutants. The removal rates of particulate matter, $\mathrm{SO}_{2}, \mathrm{NO}_{x}$, fluoride and dioxins are $97.5 \%, 96.3 \%$, $84.0 \%$ and $41.7 \%$ respectively, especially, the removal rates of PCDD/Fs were up to $95.1 \%(100 \%$ load) and $93.1 \%(60 \%$ load $)$.

(3) The sintering flue gas purification device tended to remove high chlorinated PCDD/Fs, the removal rates were sorted as follows: Octa-PCDD/Fs $>$ Hepta-PCDD/Fs $>$ Hexa-PCDD/Fs $>$ Penta$\mathrm{PCDD} / \mathrm{Fs}>$ Tetra-PCDD/Fs.

(4) The different load conditions cannot change the homologous distributions of PCDD/Fs but only impacted the emission concentrations and removal rates of $\mathrm{PCDD} / \mathrm{Fs}$ in the flue gas, which indicated that the $100 \%$ load condition resulted higher PCDD/Fs concentrations as well as the removal effects comparing with $60 \%$ loadcondition.

However, PCDD/Fs in the desulfurization and denitrification by-products were significantly concentrated in the dust ashes with $197.21 \mathrm{ng} \cdot \mathrm{TEQ} / \mathrm{m}^{3}$ and $178.56 \mathrm{ng} \cdot \mathrm{TEQ} / \mathrm{m}^{3}$. In the subsequent disposal of the desulfurization and denitrification by-products, the secondary pollution of dioxins should be investigated. At the same time, we should pay attention to the enrichments and distributions of various pollutants in the purification device and the impact on equipment operation under long-term production. Further studies are needed to investigate the formation potential and removal technology of $\mathrm{PCDD} / \mathrm{Fs}$ at China sintering plants.

Acknowledgements: This work was supported by the National Key R\&D Program of China (2018YFC0705302). The authors would also like to thank the supporting of the staff members of the steel plant for supporting us in the sampling and testing processes. 


\section{References}

1. WANG, H., ZHANG, L., Analysis of Key Sources of Smoke and Dust in Iron and Steel Enterprises. Environ. Eng., 34(3), 2016, 62-64.

2. ALCOCK, R., GEMMILL, R., JONES, K., Improvements to the UK PCDD/PCDF and PCB Atmospheric Emission Inventory Following an Emission Measurement Program me. Chemosphere., 38(4), 1999, 759-770.

3. ARIES, E., ANDERSON, D., FISHER, R., PCDD/F and "Dioxin-like" PCB Emissions from Iron Ore Sintering Plants in the UK. Chemosphere., 65(9), 2006, 1470-1480.

4. WANG, H., SONG, Q., YAO, Q., Experimental Study on the Removal of Fine Particles in Flue Gas by Wet Desulfurization system of power plant. Proc. Chin. Soc. Electric. Eng., 28(5), 2008, 1-7.

5. JIAN, C., LIU, K., ZHANG, X., Chongqing Thermal Power Plant Dioxin Atmospheric Emission Survey. Energ. Environ., 22(5), 2016, 63-64.

6. NIE, Z., YUE, B., WANG, Q., Perspective on China's Dioxin Reduction Goal. Water. Air. Soil. Pollution., 225(4), 2014, 1-4.

7. ONOFRIO, M., SPATARO, R., BOTTA, S., Deposition Fluxes of PCDD/Fs in the Area Surrounding a Steel Plant in Northwest Italy. Environ. Monitor. Assess., 186(6), 2014, 3917-3929.

8. ANDERSON, D., FISHER, R., Sources of Dioxins in the United Kingdom: the Steel Industry and Other Sources. Chemosphere., 46(3), 2002, 371-381.

9. LIU, G., ZHENG, M., CAI, Z., Dioxin Analysis in China. TrAC Trends in Analytical Chemistry. 46, 2013, 178-188.

10. ZENG, L., CHEN, G., CHEN, H., Comparative Study on Flow-Accelerated Corrosion and Erosion-Corrosion at a $90^{\circ}$ Carbon Steel Bend. Materials, 13(7), 2020, 1780-1796.

11. CHEN, H., FAN, D., HUANG, J., HUANG, W., ZHANG, G., HUANG, L., Finite Element Analysis Model on Ultrasonic Phased Array Technique for Material Defect Time of Flight Diffraction Detection. Sci. Adv. Mater., 12(5), 2020, 665-675.

12. CHENG, Y., SONG, Z., JIN, J., WANG, J., WANG, T., Experimental study on stress wave attenuation and energy dissipation of sandstone under full deformation condition. Arab. J. Geosci., 12(23), 2019, 736-749.

13. WANG, H., WANG, J., LU, H., BO, G., ZHANG, X., CAO, Y., LIU, L., ZHANG, J., ZHANG, W., Analysis of coating electrode characteristics in the process of removing pollutants from wastewater. Fresenius. Environ. Bull., 29(2), 2020, 715-721.

14. HAIBIN, L., ZHENLING, L., Recycling utilization patterns of coal mining waste in China. Resour. Conserv. Recycl., 54(12), 2010, 1331-1340.

15. GU, F., GUO, J., ZHANG, W., SUMMERS, P. A., HALL, P., From waste plastics to industrial raw materials: A life cycle assessment of mechanical plastic recycling practice based on a real-world case study. Sci. Total. Environ., 601, 2017, 1192-1207.

16. LIU, Z., FENG, J., WANG, J., Resource-Constrained Innovation Method for Sustainability: Application of Morphological Analysis and TRIZ Inventive Principles. Sustainability, 12(3), 2020, 917-939.

17. WANG, M., ZHANG, D., CHENG, Y., TAN, S. K., Assessing performance of porous pavements and bioretention cells for stormwater management in response to probable climatic changes. $J$. Environ. Manage., 243, 2019, 157-167.

18. WANG, H., AN, X., ZHANG, Z., Effect of advanced treatment on ammonia nitrogen contained in secondary effluent from wastewater treatment plant. Fresenius. Environ. Bull., 27(4), 2018, 20432050 .

19. WANG, H., ZHONG, H., BO, G., Existing forms and changes of nitrogen inside of horizontal subsurface constructed wetlands. Environ. Sci. Poll. Res., 25(1), 2018, 771-781.

20. QUAN, Q., HAO, Z., XIFENG, H., JINGCHUN, L., Research on water temperature prediction based on improved support vector regression. Neur. Comp. App., 2020, 1-10. 
21. LIU, Y. X., YANG, C. N., SUN, Q. D., WU, S. Y., LIN, S. S., CHOU, Y. S., Enhanced embedding capacity for the SMSD-based data-hiding method. Signal Processing: Image. Commun., 78, 2019, 216-222.

22. CAO, Y., WANG, Q., FAN, Q., NOJAVAN, S., JERMSITTIPARSERT, K., Risk-constrained stochastic power procurement of storage-based large electricity consumer. J. Energy. Stor., 28, 2020, 101183-101192.

23. CAO, Y., LI, Y., ZHANG, G., JERMSITTIPARSERT, K., NASSERI, M., An efficient terminal voltage control for PEMFC based on an improved version of whale optimization algorithm. Energy Reports, 6, 2020, 530-542.

24. GU, F., GUO, J., YAO, X., SUMMERS, P. A., WIDIJATMOKO, S. D., HALL, P., An investigation of the current status of recycling spent lithium-ion batteries from consumer electronics in China. $J$. Clean. Prod., 161, 2017, 765-780.

25. LIU, X., MENG,.Y., Gas-phase and Particle-phase PCDD/F Congener Distributions in the Flue Gas from an Iron Ore Sintering Plant. J. Environ. Sci., 54(4), 2017, 239-245.

26. SU, G., HUANG, L., LIU, S., The Combined Disposal of 1,2,4-Trichlorobenzene and Nitrogen Oxides Using the Synthesized Ce0.2TiAlaOx Micro/Nanomaterial. Catal. Sci. Technol., 5(2), 2015, 1041-1051.

27. JONES, J., ROSS, J., The Development of Supported Vanadia Catalysts for the Combined Catalytic Removal of the Oxides of Nitrogen and of Chlorinated Hydrocarbons from Flue Gases. Catal. Today., 35(1), 1997, 97-105.

28. Hung, P., Lo, W., Chi, K., Reduction of Dioxin Emission by a Multi-Layer Reactor with Beadshaped Activated Carbon in Simulated Gas Stream and Real Flue Gas of a Sinter Plant. Chemosphere., 82(1), 2011, 72-77.

29. CHANG, Y., HUNG, C., CHEN, J., Minimum Feeding Rate of Activated Carbon to Control Dioxin Emissions from a Large-Scale Municipal Solid Waste Incinerator. J. Hazard. Mater., 161(2-3), 2009, 1436-1443.

30. TEJIMA, H., NAKAGOWA, I., SIHINIDA, T., PCDD/Fs Reduction by Good Combustion and Fabric Filter with/without Activated Carbon Injection. Chemosphere., 32(1), 1996, 169-175.

31. KIM, S., JEON, S., JUNG, I., Removal Efficiencies of PCDDs/PCDFs by Air Pollution Control Devices in Municipal Solid Waste Incinerators. Chemosphere., 43(4-7), 2001, 773-776.

32. KARADENIR, A., BAKOGLU, M., TASPINAR, F., Removal of PCDD/Fs from Flue Gas by a Fixed-Bed Activated Carbon Filter in a Hazardous Waste Incinerator. Environ. Sci. Technol., 38(4), 2004, 1201-1207.

33. WANG, L., LEE, W., LEE, W., Effect of Chlorine Content in Feeding Wastes of Incineration on the Emission of Polychlorinated Dibenzop-Dioxins/Dibenzofurans. Sci. Total. Environ., 302(1-3), 2003, 185-198.

34. WANG, Y., LIN, C., CHANG-CHIEN, P., Characteristics of PCDD/Fs in a Particles Filtration Device with Activated Carbon Injection. Aero. Air. Qual. Res., 9(3), 2009, 317-322.

35. BA, T., ZHENG, M., ZHANG, B., Estimation and Congener-Specific Characterization of Polychlorinated Naphthalene Emissions from Secondary Nonferrous Metallurgical Facilities in China. Environ. Sci. Technol., 44(7), 2010, 2441-2446.

36. BERG, M., BIRNBAUM, L., DENISON, M., The 2005 World Health Organization Reevaluation of Human and Mammalian Toxic Equivalency Factors for Dioxins and Dioxin-Like Compounds. Toxicol. Sci., 93(2), 2006, 223-241.

37. SUN, Y., LIU, L., FU, X., Mechanism of Unintentionally Produced Persistent Organic Pollutant Formation in Iron Ore Sintering. J. Hazard. Mater., 306(1), 2016, 41-49.

38. VOGG, H., STIEGLITZ, L,. Thermal Behavior of PCDD/PCDF in Fly Ash Frommunicipal Incinerators. Chemosphere., 15(9-12), 1986, 1373-1378.

39. YAN, J., CHEN, T., LI, X., Evaluation of PCDD/Fs Emission from Fluidized Bed Incinerators CoFiring MSW with Coal in China. J. Hazard. Mater., 135(1-3), 2006, 47-51. 
40. Li, J., Lv, Z., Du, L., Emission Characteristic of Polychlorinated Dibenzo- p -Dioxins and Polychlorinated Dibenzofurans (PCDD/Fs) from Medical Waste Incinerators (MWIs) in China in 2016: A Comparison between Higher Emission Levels of MWIs and Lower Emission Levels of MWIs. Environ. Poll., 221, 2016, 437-444.

41. ZHANG, Y., ZHU, R., YANG, L., Polychlorinated Dibenzo-p-Dioxins and Dibenzofurans in OffGas and Residue during Desulphurisation of Iron Ore Sintering Off-Gas. Int. J. Environ. Poll., 63(4), 2018, 271-282.

42. LIN, X., YAN, M., DAI, A., Simultaneous Suppression of PCDD/F and $\mathrm{NO}_{\mathrm{x}}$ during Municipal Solid Waste Incineration. Chemosphere., 126, 2015, 60-66.

43. LIU, X., ZHOU, X., ZHU, B., HE, K., WANG, P., Measuring the maturity of carbon market in China: an entropy-based TOPSIS approach. J. clean. Prod., 229(1), 2019, 94-103.

44. ZHU, B., ZHOU, X., LIU, X., WANG, H., HE, K., WANG, P., Exploring the risk spillover effects among China's pilot carbon markets: A regular vine copula-CoES approach. J. Clean. Prod., 242, 2020, $1-7$.

45. WANG, P., LI, J. B., BAI, F. W., LIU, D. Y., XU, C., ZHAO, L., WANG, Z. F., Experimental and theoretical evaluation on the thermal performance of a windowed volumetric solar receiver. Energy, 119, 2017, 652-661.

46. LEI, Z., GAO, H., CHANG, X., ZHANG, L., WEN, X., WANG, Y., An application of green surfactant synergistically metal supported cordierite catalyst in denitration of Selective Catalytic Oxidation. J. Clean. Prod., 249, 2020, 1-26.

47. WANG, G., WANG, F., SHEN, F., JIANG, T., CHEN, Z., HU, P., Experimental and optical performances of a solar CPV device using a linear Fresnel reflector concentrator. Renew. Energy., 146, 2020, 2351-2361.

48. WANG, Y., CAO, L., HU, P., LI, B., LI, Y., Model establishment and performance evaluation of a modified regenerative system for a $660 \mathrm{mw}$ supercritical unit running at the IPT-setting mode. Energy, 179, 2019, 890-915.

49. CAO, L., TU, C., HU, P., LIU, S., Influence of solid particle erosion (SPE) on safety and economy of steam turbines. Appl. Therm. Eng., 150, 2019, 552-563.

50. LEI, Z., JIHAO, C., ZHANG, L., HUIBIN, H., YUSU, W., YONGHUI, L., Preparation of soybean oil factory sludge catalyst and its application in selective catalytic oxidation denitration process. $J$. clean. Prod., 225, 2019, 220-226.

Manuscript received: 17.03 .2020 